\title{
EFFECTS OF SAMBILOTO ETHANOL EXTRACT ON FATTY LIVER, SGOT/SGPT LEVELS AND LIPID PROFILE OF WISTAR STRAIN WHITE RAT (Rattus norvegicus) EXPOSED TO HIGH-FAT DIET
}

\author{
FX Himawan Haryanto Jong ${ }^{1,2}$, Ari Gunawan ${ }^{1}$, Mochamad Wirono Aman Santoso ${ }^{1}$, Susilowati Andajani ${ }^{3}$, \\ Ni Wajan Tirthaningsih", Ahmad Basori ${ }^{4}$ \\ ${ }^{1}$ Department of Anatomy and Histology, Faculty of Medicine, Universitas Airlangga, ${ }^{2}$ Department of Anatomy and \\ Histology, Faculty of Medicine, Universitas Katolik Widya Mandala Surabaya, ${ }^{3}$ Department of Public Health and \\ Preventive Medicine, ${ }^{4}$ Department of Pharmacology, Faculty of Medicine, Universitas Airlangga, Surabaya, Indonesia
}

\begin{abstract}
ABSTRAK
Tujuan dari studi ini adalah untuk menganalisis pengaruh pemberian ekstrak etanol sambiloto (Andrographis paniculata) terhadap persentase perlemakan hati, kadar serum glutamic oxaloacetic transaminase (SGOT)/serum glutamic pyruvic transaminase (SGPT) dan profil lipid tikus Wistar jantan yang dipapar diet tinggi lemak. Rancangan penelitian yang digunakan adalah the randomised post test only control group design. Total besar sampel adalah 50 ekor tikus putih Rattus norvegicus strain Wistar jantan yang terbagi secara acak dalam 5 kelompok (randomisasi). Uji normalitas yang digunakan adalah uji Kolmogorov Smirnov ( $\alpha=0,05)$. Uji homogenitas yang digunakan adalah uji Levene $(\alpha=0,05)$. Uji beda dengan menggunakan uji Anova (analysis of variance) $(\alpha=0,05)$ atau uji Brown-Forsythe $(\alpha=0,05)$. Uji korelasi yang digunakan adalah uji Pearson $(\alpha=0,05)$. Pemberian ekstrak etanol sambiloto dengan dosis 100, 200 dan 400 miligram $(\mathrm{mg}) /$ kilogram $(\mathrm{kg})$ berat badan $(\mathrm{BB})$ dapat menurunkan persentase perlemakan hati $(r=-$ 0,950), kadar SGOT ( $r=-0,964) / S G P T(r=-0,917)$ dan kadar kolesterol total $(r=-0,923) / T G($ trigliserida $)(r=-0,973) / L D L($ lowdensity lipoprotein) ( $r=-0,960)$ serta meningkatkan kadar HDL (high-density lipoprotein) $(r=0,956)$ tikus putih yang dipapar diet tinggi lemak. Sebagai simpulan, peningkatan dosis ekstrak etanol sambiloto dapat menurunkan persentase perlemakan hati, kadar SGOT/ SGPT dan kadar kolesterol total/TG/LDL serta meningkatkan kadar HDL tikus putih yang dipapar diet tinggi lemak. (FMI 2018;54:89-95)
\end{abstract}

Kata kunci: Perlemakan hati; Andrographis paniculata; SGOT/SGPT; profil lipid

\begin{abstract}
The aim of this study was to analyze the effects of ethanol extract of sambiloto (Andrographis paniculata) on fatty liver percentage, serum glutamic oxaloacetic transaminase (SGOT) level and lipid profile of wistar strain white rat exposed to high fat diet. The study used randomized post test only control group design. Total sample was 50 male wistar strain rats (Rattus norvegicus) divided randomly into 5 groups (randomization). The normality test used was Kolmogorov Smirnov test $(\alpha=0.05)$. The homogeneity test used was Levene test $(\alpha=0.05)$. The comparative test was done using Anova test (analysis of variance) $(\alpha=0.05)$ or Brown-Forsythe test $(\alpha=0.05)$. The correlation test was done using Pearson test $(\alpha=0.05)$. The administration of sambiloto ethanol extract with doses of 100, 200 and 400 milligrams $(\mathrm{mg}) / \mathrm{kilogram}(\mathrm{kg})$ body weight $(\mathrm{BW})$ decreased the percentage of fatty liver $(r=-0.950)$, SGOT $(r=-$ $0.964) / S G P T(r=(R=-0.973) / L D L$ (low-density lipoprotein) $(r=-0.960)$ and increased HDL (high-density lipoprotein) levels ( $r=-$ $0.923)=0.956$ ) in white rats exposed to a high-fat diet. In conclusion, increased dose of ethanol extract of sambiloto can decrease the percentage of fatty liver, SGOT/SGPT and total cholesterol/TG/LDL and increase HDL level of white rats exposed to high fat diet. (FMI 2018;54:89-95)
\end{abstract}

Keywords: Fatty liver; Andrographis paniculata; SGOT/SGPT; lipid profile

Correspondence: FX Himawan Haryanto Jong, Department of Anatomy and Histology, Faculty of Medicine, Universitas Airlangga. Email: fxhimawanharyanto@gmail.com

\section{INTRODUCTION}

Non-alcoholic fatty liver disease (NAFLD) becomes a pandemic in the world nowadays. Around one billion people worldwide suffer from this disease. Epidemiological data shows that $25 \%$ of population in Asia Pacific, including in Indonesia, suffer from NAFLD, and about $10-20 \%$ of these numbers suffer from more severe forms of the disease, i.e. non-alcoholic steatohepatitis (NASH) and cirrhosis. More severe problem that threatens NAFLD patients is the increased risk of liver failure and liver cancer (World Gastroenterology Organization 2012, Mahady \& George 2013).

Non-alcoholic fatty liver disease is a liver disease that is characterized by the appearance of ectopic fat in the 
liver. Inflammatory reactions due to fatty liver accumulation in NAFLD are not caused by alcohol consumption (Machado \& Cortez-pinto 2014, Kumar et al 2013). Non-alcoholic fatty liver disease has close correlation with metabolic syndrome. High-fat diets and carbohydrates, obesity and lack of motion are considered as the causes of this syndrome (Vornoli et al 2014). Nonalcoholic fatty liver disease is a form of metabolic syndrome in the liver that results from fat accumulation in the liver (Takaki et al 2013).

The multi-hit hypothesis is widely accepted by experts as the pathogenesis of NAFLD (Campana et al 2015). Insulin resistance is a major factor in this pathogenesis that causes the accumulation of free fatty acids in the liver. Fatty deposits give rise to oxidative stress and inflammatory processes in liver tissue. All of these factors apparently complicate the disease. The results of previous studies have not revealed the most effective treatment for the disease (Kumar et al 2013, Takaki et al 2013).

Male wistar strain rats exposed to a high-fat diet in several studies showed the accumulation of free fatty acids in the liver (Romestaing et al 2007, Kucera \& Cervinkova 2014). Vornoli et al (2014) used animal models of male wistar rats exposed to a high-fat diet (29\% fat). The histopathology of male wistar rat liver in this study demonstrated the fatty liver characterized by steatosis.

Results of SGOT and SGPT, blood glucose levels and lipid profile, total cholesterol, triglycerides (TG), and LDL (low-density lipoprotein) examinations showed significant increase, while the HDL (high-density lipoprotein) showed a decrease. These animal models resembled the condition of individuals with NAFLD.

Andrographis paniculata, known as sambiloto, is one of the popular medicinal plants in Indonesia for the treatment of various diseases. The useful bioactive components of the plant's extracts are especially lactones and flavones, which are known to be hepatoprotective (Bardi et al 2014). Hepatoprotective properties are obtained from, among others, their capacity as an anti-oxidant and anti-inflammatory. The hepatoprotective properties present in the sambiloto extract are thought to play a role in reducing liver damage in NAFLD. Sambiloto's bioactive agent also has a capacity to inhibit the accumulation of cholesterol and triglycerides in liver tissue since the agent has properties which may inhibit the transcription factor for cholesterol absorption (Jayakumar et al 2013, Negi et al 2008). The aim of this study was to analyze the effect of ethanol extract of sambiloto on fatty liver, SGOT (serum glutamic oxaloacetic transaminase) and SGPT (serum glutamic pyruvic transaminase) and lipid profile of male wistar rats exposed to high-fat diet.

\section{MATERIALS AND METHODS}

This study used randomized post test only control group design. Total sample was 50 male wistar strain rats, divided into 5 groups randomly. Each group consisted of 10 rats. The first two groups were control groups. In control groups, the rats received standard diet from day 1 to 84. High-fat diet was administered to positive control group with the same duration as the first group. Three other groups received high-fat diet for 84 days using sonde with ethanol extract of sambiloto in doses of, respectively, $100 \mathrm{mg} / \mathrm{kg} \mathrm{BW}, 200 \mathrm{mg} / \mathrm{kg} \mathrm{BW}$ and $400 \mathrm{mg} / \mathrm{kg} \mathrm{BW}$ every two days from days 71-84.

Total rat cholesterol levels from all groups were examined on the first day of the experimental study. Total cholesterol levels were examined by cutting the rats' tails as much as $0.5 \mathrm{~mm}$ and the blood was dripped on the sticks on analyzer. The same examination was performed again on days 70 and 85 . The data of total cholesterol on days 1 and 70 was tested by Levene normality test $(\alpha=0.05)$, homogeneity test of Kolmogorov Smirnov ( $\alpha=0.05)$, and One-way Anova $(\alpha=0.05)$ to observe normal and homogeneous distributions of all groups of rats before high-fat diet. Ethanol extract therapy was applied.

On the day 85 , the rats were anesthetized and cardiac puncture was performed for blood sampling for SGOT, SGPT, TG (triglyceride), LDL (low-density lipoprotein) and HDL (high-density lipoprotein). Thereafter, the rats were sacrificed and the liver was removed to be put into formalin for the preparation of the histotechnical process. Histologic preparations were made from liver and observed under light microscope with 400 times magnification. The percentage of hepatocyte cells undergoing steatosis was calculated in 10 visual fields.

The rats were fasted for 10 hours before blood collection at all examinations. All data were collected to be presented as descriptive data and further processed for statistical analysis using Statistical Software for Social Sciences 16 (SPSS 16). Normality test was conducted using Kolmogorov Smirnov test $(\alpha=0.05)$ and homogeneity test using Levene test $(\alpha=0.05)$. If data distribution was normal $(\mathrm{p}>0.05)$ and homogeneous ( $>0.05)$, the Anova test $(\alpha=0.05)$ was performed. If data distribution was not normal $(\mathrm{p}<0.05)$ and not homogeneous $(\mathrm{p}<0.05)$, the Brown-Forsythe $(\alpha=0.05)$ test was performed. The correlation test used in this study was Pearson's correlation test $(\alpha=0.05)$ since all data were of ratio type. 


\section{RESULTS}

\section{Fatty liver percentage}

The histological general description of the liver in negative control group indicated normal liver histology. A positive control group who received high-fat diet without therapy showed fatty liver histology with a seemingly inexact parenchyma and many hepatocyte defects. Histologic profile of the liver in group of rats receiving sambiloto ethanol extract therapy showed histological improvement. The histologic profile of liver of the white rats can be seen in Fig. 1.

Fatty liver percentage data were normal $(\mathrm{p}>0.05)$ but not homogeneous $(\mathrm{p}<0.05)$, so we used Brown Forsythe test to find difference between goups. It turned out that the differences were significant $(\mathrm{p}<0.05)$. Mean percentage of rats fatty liver in negative and positive control groups was $0.09 \pm 0.01 \%$ and $9.35 \pm 0.55 \%$, while mean percentage fatty liver in rats receiving ethanol extract of sambiloto of $100 \mathrm{mg} / \mathrm{kg} \mathrm{BW}, 200 \mathrm{mg} / \mathrm{kg} \mathrm{BW}$ and 400 $\mathrm{mg} / \mathrm{kg} \mathrm{BW}$ were $7.65 \pm 0.45 \%, 6.67 \pm 0.38 \%$ and $5.58 \pm$ $0.38 \%$ respectively. Pearson's correlation test results showed that there was a strong correlation $(r=-0.950)$ between increasing dose of sambiloto ethanol extract and decreasing percentage of fatty liver.

\section{SGOT and SGPT levels}

Data of SGOT and SGPT levels were normal ( $p>0.05)$ and homogeneous $(\mathrm{p}<0.05)$, so we used Anova test to find difference between groups. There were significant differences in both levels between groups $(\mathrm{p}<0.05)$.
The mean SGOT levels in negative and positive control groups were $159.90 \pm 4.77$ IU (international unit)/L (liter) and 260.20 $\pm 3.19 \mathrm{IU} / \mathrm{L}$, while the mean SGOT levels in rats receiving sambiloto ethanol extract of 100 $\mathrm{mg} / \mathrm{kg} \mathrm{BW}, 200 \mathrm{mg} / \mathrm{kg} \mathrm{BW}$ and $400 \mathrm{mg} / \mathrm{kg} \mathrm{BW}$ were respectively $213.20 \pm 4.64 \mathrm{IU} / \mathrm{L}, 190.30 \pm 3.56 \mathrm{IU} / \mathrm{L}$ and $174.30 \pm 2.79 \mathrm{IU} / \mathrm{L}$.

The mean SGPT levels in negative and positive control groups were $53.80 \pm 3.55 \mathrm{IU} / \mathrm{L}$ and $102.90 \pm 4.82 \mathrm{IU} / \mathrm{L}$, while the mean SGPT levels in rats receiving sambiloto ethanol extract of $100 \mathrm{mg} / \mathrm{kg} \mathrm{BW}, 200 \mathrm{mg} / \mathrm{kg} \mathrm{BW}$ and $400 \mathrm{mg} / \mathrm{kg} \mathrm{BW}$ were $85.80 \pm 4.13 \mathrm{IU} / \mathrm{L}, 82.90 \pm 3.96 \mathrm{IU} / \mathrm{L}$ and 68.90 $\pm 4.68 \mathrm{IU} / \mathrm{L}$, respectively.

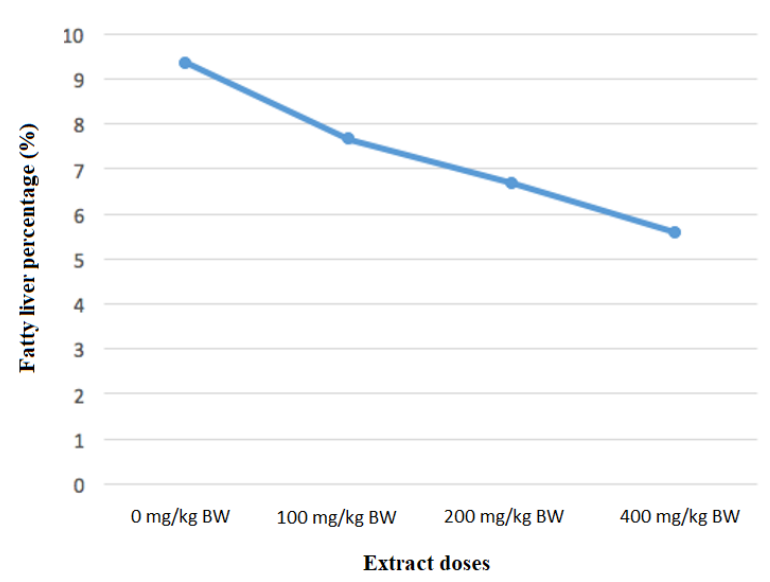

Fig. 2. The correlation of extract dose increase with fatty liver percentage.

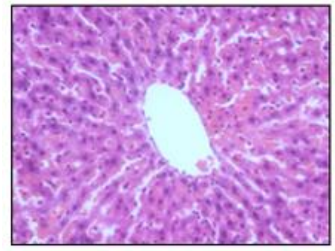

a

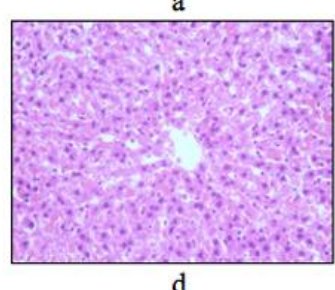

d

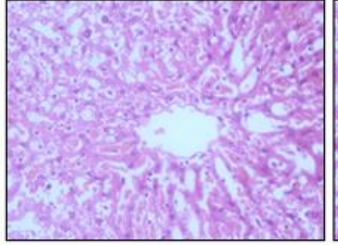

b

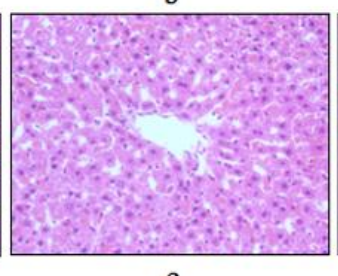

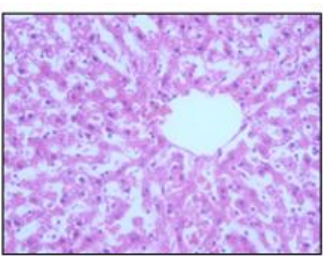

c

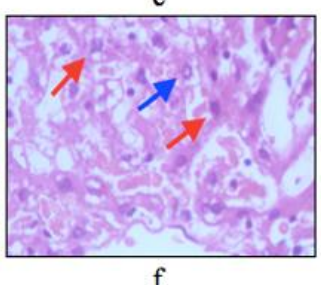

Fig. 1. Histological profile of the liver in: a) negative control group, b) positive control group, c) group with $100 \mathrm{mg} / \mathrm{kg}$ BW sambiloto ethanol extract therapy, d) group with $200 \mathrm{mg} / \mathrm{kg} \mathrm{BW}$ sambiloto ethanol extract therapy, e) group with $400 \mathrm{mg} / \mathrm{kg} \mathrm{BW}$ sambiloto ethanol extract therapy, and f) blue arrows showed normal samples of hepatocytes and red arrows showed examples of steatotic hepatocytes. 
Table 1. Results of the study

\begin{tabular}{lccccc}
\hline $\begin{array}{c}\text { Parameter } \\
\text { Mean } \pm \text { SD })\end{array}$ & Negative control & Positive control & $\begin{array}{c}100 \mathrm{mg} / \mathrm{kg} \mathrm{BW} \\
\text { extract dose }\end{array}$ & $\begin{array}{c}200 \mathrm{mg} / \mathrm{kg} \mathrm{BW} \\
\text { extract dose }\end{array}$ & $\begin{array}{c}400 \mathrm{mg} / \mathrm{kg} \mathrm{BW} \\
\text { extract dose }\end{array}$ \\
\hline$\%{ }^{1,4}$ & $0.09 \pm 0.01$ & $9.35 \pm 0.55$ & $7.65 \pm 0.45$ & $6.67 \pm 0.38$ & $5.58 \pm 0.38$ \\
$\mathrm{SGOT}^{1,2,3}$ & $159.90 \pm 4.77$ & $260.20 \pm 3.19$ & $213.20 \pm 4.64$ & $190.30 \pm 3.56$ & $174.30 \pm 2.79$ \\
$\mathrm{SGPT}^{1,2,3}$ & $53.80 \pm 3.55$ & $102.90 \pm 4.82$ & $85.80 \pm 4.13$ & $82.90 \pm 3.96$ & $68.90 \pm 4.68$ \\
$\mathrm{Kol}^{1,2,3}$ & $102.90 \pm 2.88$ & $140.90 \pm 2.42$ & $122.20 \pm 3.79$ & $116.50 \pm 2.07$ & $110.30 \pm 3.62$ \\
$\mathrm{TG}^{1,4}$ & $48.90 \pm 7.59$ & $108.00 \pm 3.68$ & $83.00 \pm 3.80$ & $71.80 \pm 2.10$ & $54.30 \pm 4.85$ \\
$\mathrm{LDL}^{1,2,3}$ & $12.40 \pm 1.71$ & $38.80 \pm 2.30$ & $32.80 \pm 1.62$ & $28.60 \pm 1.43$ & $22.50 \pm 1.58$ \\
$\mathrm{HDL}^{1,2,3}$ & $62.10 \pm 3.14$ & $41.90 \pm 2.33$ & $51.00 \pm 1.94$ & $55.80 \pm 2.25$ & $61.70 \pm 1.64$ \\
\hline
\end{tabular}

Note: \%: percentage of fatty liver, SGOT: SGOT levels on day 85, SGPT: SGPT levels on day 85, Col: cholesterol levels on day 85 , TG: triglyceride levels on day 85, LDL: LDL levels on day 85, HDL: HDL levels on day 85, 1: normal data distribution, $\mathrm{p}>0.05,2$ : homogeneous data distribution, $\mathrm{p}>0.05,3$ : Anova test results, $\mathrm{p}<0.05$, 4: Brown-Forsythe test results, $\mathrm{p}<0.05$

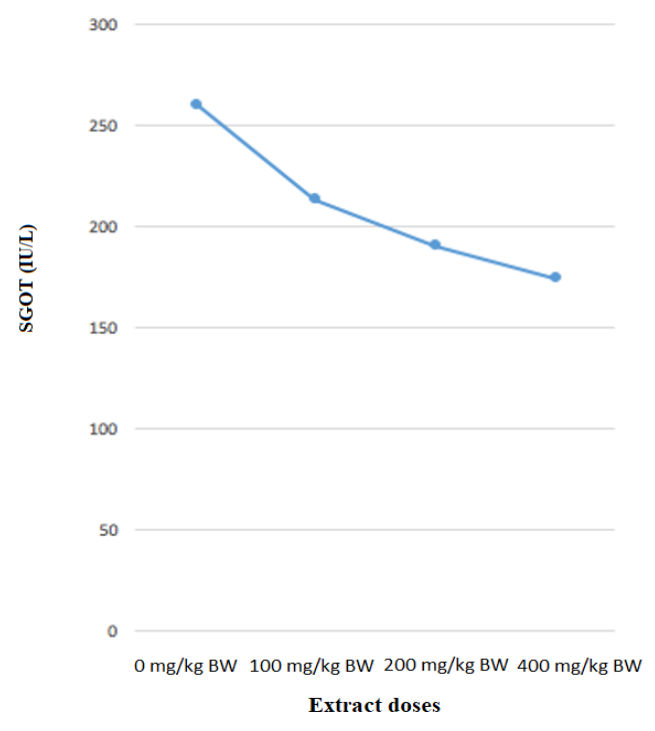

Fig. 3. The correlation of extract dose increase with SGOT levels.

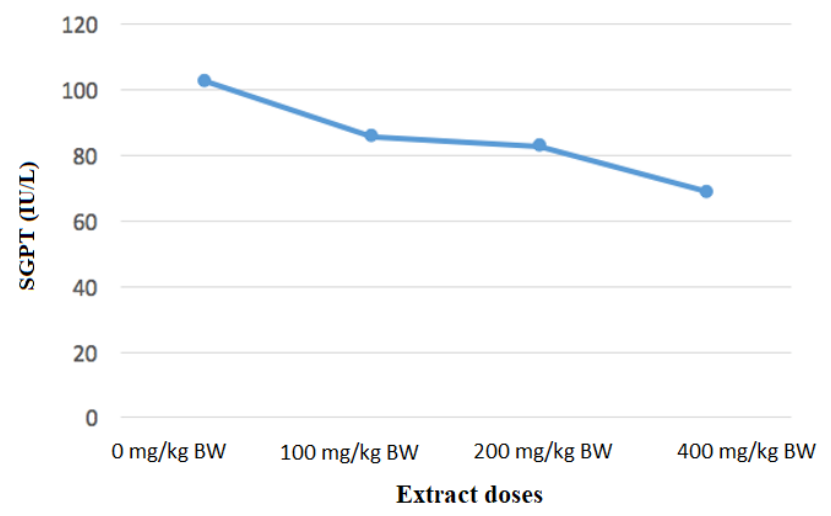

Fig. 4. The correlation of extract dose increase with SGPT levels.
Pearson correlation test results showed that there was strong correlation between increasing dose of sambiloto ethanol extract with decreasing SGOT (r=-0.964) and SGPT ( $r=-0.917)$ levels.

\section{Lipid profile}

Distribution of total cholesterol data on day 1 and 70 was normal $(p>0.05)$ and homogeneous $(p>0.05)$ and there was no significant difference between groups ( $>0.05$ ). This test proved that experimental white rats were in normal and homogeneous conditions before the treatment of high-fat diet and sambiloto ethanol extract therapy (on day 71) began.

Data on total cholesterol level on day 85, LDL level and HDL level were normal ( $p>0.05)$ and homogeneous ( $>0.05$ ), so that the different test between groups used was Anova test. Data of TG level were normal ( $>>0.05$ ) but not homogeneous $(p<0.05)$, so that we used Brown Forsythe test to find the difference between groups.

Mean total cholesterol level in negative and positive control groups were $102.90 \pm 2.88 \mathrm{mg} /$ deciliter (dl) and $140.90 \pm 2.42 \mathrm{mg} / \mathrm{dl}$, while mean total cholesterol level of rats receiving dose of sambiloto ethanol extract of $100 \mathrm{mg} / \mathrm{kg} \mathrm{BW}, 200 \mathrm{mg} / \mathrm{kg}$ BW and $400 \mathrm{mg} / \mathrm{kg}$ BW were $122.20 \pm 3.79 \mathrm{mg} / \mathrm{dl}, \quad 116.50 \pm 2.07 \mathrm{mg} / \mathrm{dl}$ and $110.30 \pm 3.62 \mathrm{mg} / \mathrm{dl}$ respectively.

Mean TG levels in negative and positive control groups were $48.90 \pm 7.59 \mathrm{mg} / \mathrm{dl}$ and $108.00 \pm 368 \mathrm{mg} / \mathrm{dl}$, whereas the mean TG levels of rats receiving sambiloto ethanol extract of $100 \mathrm{mg} / \mathrm{kg} \mathrm{BW}, 200 \mathrm{mg} / \mathrm{kg} \mathrm{BW}$ and 400 $\mathrm{mg} / \mathrm{kg}$ BW were $83.00 \pm 3.80 \mathrm{mg} / \mathrm{dl}, 71.80 \pm 2.10 \mathrm{mg} / \mathrm{dl}$ and $54.30 \pm 4.85 \mathrm{mg} / \mathrm{dl}$, respectively. 


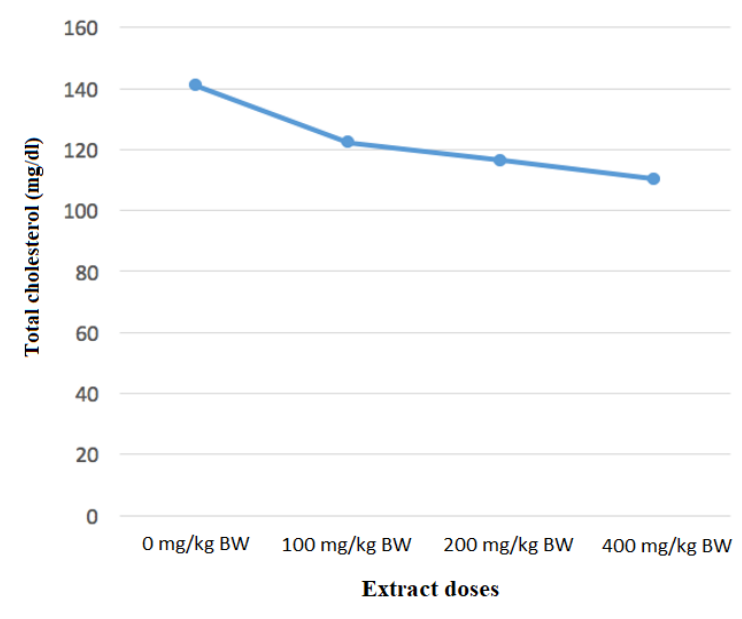

Fig. 5. The correlation of extract dose increase with total cholesterol levels.

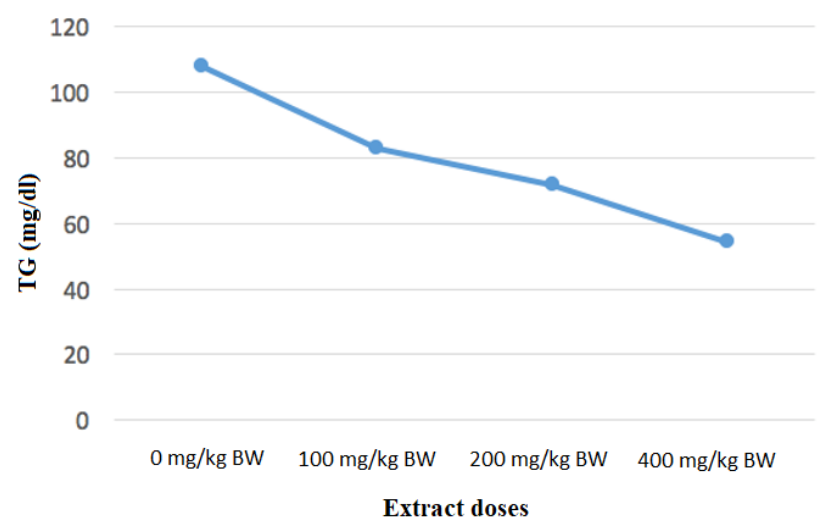

Fig. 6. The correlation of extract dose increase with TG levels.

Mean LDL levels in negative and positive control groups were $12.40 \pm 1.71 \mathrm{mg} / \mathrm{dl}$ and $38.80 \pm 2.30 \mathrm{mg} / \mathrm{dl}$, whereas the mean LDL levels of rats receiving sambiloto ethanol extract of $100 \mathrm{mg} / \mathrm{kg} \mathrm{BW}, 200 \mathrm{mg} / \mathrm{kg}$ BW and $400 \mathrm{mg} / \mathrm{kg}$ BW were $32.80 \pm 1.62 \mathrm{mg} / \mathrm{dl}$, $28.60 \pm 1.43 \mathrm{mg} / \mathrm{dl}$ and $22.50 \pm 1.58 \mathrm{mg} / \mathrm{dl}$, respectively.

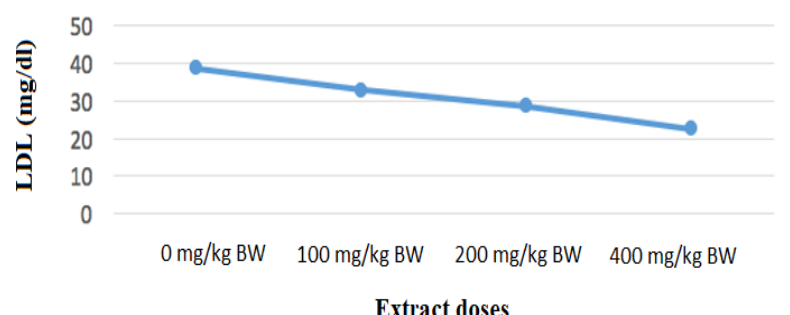

Fig. 7. The correlation of extract dose increase with LDL levels.
Mean HDL levels in negative and positive control groups were $62.10 \pm 3.14 \mathrm{mg} / \mathrm{dl}$ and $41.90 \pm 2.33 \mathrm{mg} / \mathrm{dl}$, whereas the mean HDL levels of rats receiving sambiloto ethanol extract of $100 \mathrm{mg} / \mathrm{kg} \mathrm{BW}, 200 \mathrm{mg} / \mathrm{kg} \mathrm{BW}$ and $400 \mathrm{mg} / \mathrm{kg} \mathrm{BW}$ were $51.00 \pm 1.94 \mathrm{mg} / \mathrm{dl}, 55.80 \pm 2.25$ $\mathrm{mg} / \mathrm{dl}$ and $61.70 \pm 1.64 \mathrm{mg} / \mathrm{dl}$, respectively.

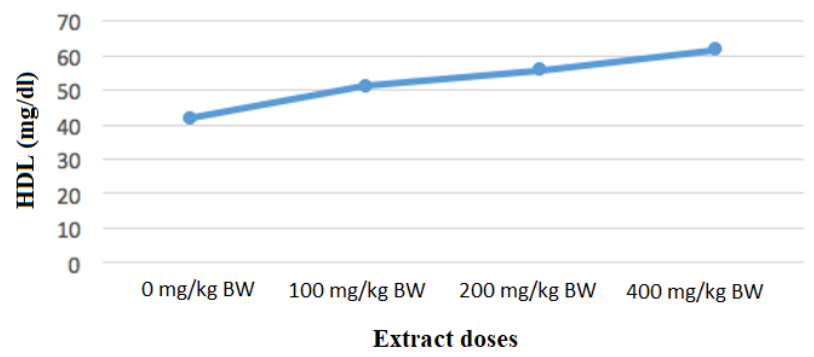

Fig. 8. The correlation of extract dose increase with HDL levels.

The results of Pearson's correlation test showed that there was a strong correlation between increased dose of sambiloto ethanol extract with decreased total cholesterol $(\mathrm{r}=-0.923)$, TG $(\mathrm{r}=-0.973)$ and LDL $(\mathrm{r}=-0.960)$ levels on day 85. There was a strong correlation between increased dose of ethanol extract of sambiloto with increased HDL levels ( $\mathrm{r}=0.956)$.

\section{DISCUSSION}

\section{Fatty liver percentage}

Oxidative stress plays an important role in causing steatosis in hepatocytes. The accumulation of free fatty acids triggers mitochondrial action to maintain the stability of hepatocyte cells. Continuous accumulation will cause mitochondrial damage that ends with the accumulation of free radicals in the liver tissue. The accumulation of free radicals will lead to cell damage and ultimately cell death (Vornoli et al 2014, Takaki et al 2013).

The bioactive components of lactones and flavones contained in sambiloto extract can decrease the production of TNF- $\alpha$ which is triggered by intercellular adhesion molecule- 1 and endothelial monocyte adhesion that occurs when the cells are undergoing an inflammatory process. In addition, these bioactive substances in the extract have anti-inflammatory capabilities by preventing NF- $\kappa \mathrm{B}$ bonds by DNA and proinflammatory cytokine production will be inhibited (Jarukamjorn \& Nemoto 2008, Jayakumar et al 2013).

Sambiloto ethanol extract through its bioactive component also has antioxidant effect. This effect is thought to be obtained through its capacity as a free 
radical scavenger in tissues by providing electron donors to these free radicals. Another possibility is the bioactive substance of ethanol extract of sambiloto improves the function of mitochondria and other cell organelles as the defense of the cells against free radicals (Koh et al 2013, Jayakumar et al 2013).

\section{SGOT and SGPT levels}

NAFLD diagnosis based on laboratory blood testing only is still not possible, but the use of SGOT and SGPT, as they are actually serum transaminase, can be applied as a first step (Berlanga et al 2014). The accumulation of free fatty acids in the liver that results in inflammatory reactions and oxidative stress causes hepatocytes to leak out of the plasma membrane. Hepatocyte cell damage can be indicated by elevated levels of transaminase enzyme in the blood (Koh et al 2013). Several studies have demonstrated the potential of sambiloto ethanol extracts in improving liver function in various conditions, such as hepatitis B disease or exposure to toxic substances to the liver, such as acetaminophen or carbon tetrachloride. Liver transaminase enzyme in the blood may decrease with the administration of the extract (Jayakumar et al 2013).

Provision of sambiloto ethanol extracts in white rats exposed to high-fat diet in this study was able to reduce the levels of SGOT and SGPT in the rats' blood. Decreased levels had a strong correlation with increasing doses of the extract. A study conducted by Bardi et al (2014) using experimental animal models with liver damage due to induction of thioacetamide indicated that the bioactive substance of sambiloto ethanol extract may have hepatoprotective effect through its capacity to inhibit various factors that cause cell death (apoptosis). Hepatoprotective effects are also obtained through antiinflammatory and antioxidant activity of bioactive components.

\section{Lipid profile}

Sterol regulatory element-binding protein is a major transcription factor in tissue fat storage bound to cell membranes. Hepatic lipogenesis is governed by type 1c of this transcription factor (SREBP1c). Some studies has shown that increased expression of SREBP1c in liver tissue is associated with NAFLD (Berlanga et al 2014). Free fatty acids will be stored in the form of triglycerides in liver tissue under high-fat dietary conditions. Increased lipogenesis in non-adipose tissue such as the liver can cause tissue destruction because saturated fats may have free radical characeristics that cause inflammatory reactions and oxidative stress (Chen et al 2014).
Increased blood cholesterol levels are associated with an increased risk of cardiovascular disease and atherosclerosis. Sambiloto ethanol extract has been widely used in the study to show the effect of extracts that have hypolipidemic biological activity that can reduce total cholesterol, TG and LDL (Jayakumar et al 2013). Total cholesterol, TG and LDL levels of white rats in the treatment groups were found to decrease in comparison with those in positive control group exposed to a highfat, non-therapeutic diet. Decreased free fatty acids in circulation is followed by a decrease in free fatty acids leading to the portal vein which reduces fat accumulation in the liver tissue.

Ding et al (2014) conducted a study showing the result that the sambiloto ethanol extract through its bioactive component was able to decrease SREBP expression on the tissue. This can be used to reduce fat accumulation in liver tissue as a cause of NAFLD. High-density lipoproteins have anti-atherogenic activity that can be useful to induce cholesterol out of tissue (Lund-Katz \& Phillips 2010). Provision of sambiloto ethanol extracts in this study proved to be able to reduce HDL levels in white rats exposed to a high-fat diet. A study conducted by Ding et al (2014) also demonstrated the ability of bioactive substances of sambiloto ethanol extracts in improving the lipid profile of white rats exposed to a high-fat diet. The sambiloto ethanol extract is thought to increase the activity of LCAT (lecithin-cholesterol acyltransferase) enzyme which is a key factor in HDL formation.

\section{CONCLUSION}

The increased dose of sambiloto ethanol extract decreases the percentage of fatty liver, SGOT/SGPT and total cholesterol/TG/DL and increases HDL level.

\section{REFERENCES}

Bardi DA, Halabi MF, Hassandarvish P, Rouhollahi E, Paydar M, et al (2014). Andrographis paniculata leaf extract prevents thioacetamide-induced liver cirrhosis in rats. Plos One 9, e109424

Berlanga A, Guiu-Jurado E, Porras JA, Auguet T (2014). Molecular pathways in non-alcoholic fatty liver disease. Clin Exp Gastroenterol 7, 221-239

Campana B, Semela D, Heim M, Bernsmeier C (2015). Non-alcoholic fatty liver disease - changing the prevalence of liver cancer? Eur Med J Hepatol 3, 1218

Chen Y, Varghese Z, Ruan XZ (2014). The molecular pathogenic role of inflammatory stress in dysregu- 
lation of lipid homeostasis and hepatic steatosis. Genes \& Diseases 1, 106-112

Ding L, Li J, Song B, Xiao X, Huang W, et al (2014). Andrographolide prevents high-fat diet-induced obesity in C57BL/6 mice by supressing the sterol regulatory element-binding protein pathway. J Pharmacol Exp Ther 351, 474-483

Jarukamjorn K, Nemoto N (2008). Pharmalogical aspects of andrographis paniculata on health and its major diterpenoid constituent andrographolide. J Health Sci 54, 370-381

Jayakumar T, Hsieh C, Lee J, Sheu J (2013). Experimental and clinical pharmacology of Andrographis paniculata and its major bioactive phytoconstituent andrographolide. Evid Based Complement Alternat Med

Koh PH, Mokhtar RAM, Iqbal M (2013). Andrographis paniculata ameliorates Carbon Tetrachloride (CCL4)dependent hepatic damage and toxicity: diminution of oxidative stress. Redox Rep 16, 135-143

Kucera O, Cervinkova Z (2014). Experimental models of non-alcoholic fatty liver disease in rats. World $\mathbf{J}$ Gastroenterol 20, 8364-8376

Kumar V, Abbas AK, Aster JC (2013). Robbins basic pathology. 9th ed. Philadelphia, Elsevier Saunders
Lund-Katz, Phillips (2010). High density lipoprotein structure-function and role in reverse cholesterol transport. Subcell Biochem 51, 183-227

Machado MV, Cortez-pinto H (2014). Non-alcoholic fatty liver disease: What the clinician needs to know. World J Gastroenterol 20, 12956-12980

Mahady SE, George J (2013). The future liver of asia pacific: Fatter and firmer from more fructose and fortune. J Clin Exp Hepatol 3, 106-113

Negi AS, Kumar JK, Luqman S, Shanker K, Gupta MM, Khanuja SPS (2008). Med Res Rev 28, 746-772

Romestaing R, Piquet M, Bedu E, Rouleau V, Dautresme M, et al (2007). Long term highly saturated fat diet does not induce NASH in wistar rats. Int $\mathrm{J}$ Nut Metab 4, 4

Takaki A, Kawai D, Yamamoto K (2013). Multiple hits, including oxidative stress, as pathogenesis and treatment target in non-alcoholic steatohepatitis (NASH). Int J Mol Sci 14, 04-28

Vornoli A, Pozzo L, Croce CMD, Gervasi PG, Longo V (2014). Drug metabolism enzymes in a steatotic model of rat treated with a high fat diet and a low dose of streptozotocin. Food Chem T 70, 54-60

World Gastroenterology Organisation (2012). Nonalcoholic fatty liver disease and nonalcoholic steatohepatitis. World Gastroenterology Organisation Global Guidelines, June 2012 